\title{
Digital Museology Under Test: Challenges and Opportunities for Russian Museums
}

\author{
Anna Guboglo
}

The current epidemic and accompanying economic stagnation instigate reflections about the role of museums in social life and about the directions they must take to increase their accessibility. In the Russian museum sector, the epidemic opened multiple discussions, allowing professionals to polemicize and seek the most suitable solutions to current problems. Some saw the importance of museums and, in fact, of all cultural institutions, as diminishing dramatically during such crises, but for others, museums represented a distraction from isolation that could compensate for the lack of social cultural activities. Those in the latter group have found themselves obligated to offer as much access as possible, and that implies a turn from the logistics of maintaining object collections toward the digital humanities.

Because cultural propagation was not declared a matter of national priority in the Russian Federation, there was no unified strategy for the lockdown. Museum directors and their colleagues most often decided by themselves on their plan of action and implemented measures in terms of staff members' technological proficiency and the availability of necessary equipment. As elsewhere in the world, museums across the country adopted several strategies: the ubiquitous virtual museum tours, intensive social media activities, artistic video or photo installations, online lectures, children's interactive and educational sessions, and posts related to the quarantine experience.

Simultaneously, some Russian museum professionals, such as Victor Shalay, director of the Far East Museum, argued against such activities. They suggested that providing a high quality image and a short description of a collection object is not sufficient and is not a viable method of serving the public during an extended building closure.1 Seldom will a potential online visitor be interested in content like a slideshow of masterpieces, since it loses ground against the huge amount of other internet entertainment. The same is true of many activities that simply aim to place a former offering in a digital format.

Instead, many Russian museums have made themselves especially visible through their active participation in managing the COVID-19 crisis and helping citizens experiencing difficulties. Certain institutions have served as models of public service and collaboration. The Garage Museum of Contemporary Art in Moscow launched the 'Everything will be good' movement, providing lunches for elderly people, medical personnel, volunteers, and immigrants. The Multimedia Art Museum, also located in the capital, inspired a flash mob across social media to gather flower paintings for the next vernissage. Moscow auction house Vladey organized an online charitable auction to assist medical workers. Showing solidarity with epidemic-stricken Italy, the State Hermitage Museum prepared 'From the Hermitage to Italy', a series of three virtual museum tours in Italian. These activities can be interpreted on two levels: while a heightened media presence increases organizations' reputations and visibility, it also demonstrates that museums and other cultural organizations, public and private, bear a sense of social responsibility during periods of crisis and act accordingly.

This being said, the most important function of museums in times of social turbulence is showing solidarity with affected people, many of whom appreciate an effort to maintain, to every possible extent, the illusion of normality. In doing so, museums fulfil an essential social mission: not letting people find themselves deprived of traditional institutions and of the possibility to educate or distract themselves. Artyom Silkin, director of the museum of the Island-Town of Sviyazhsk, has asserted that people maintain the expectations of culture to provide spiritual comfort and consolation. In the face of these expectations, the Hermitage, the symbolic flagship of Russian museums, has propagated the concept of 'intelligent isolation', 
implying that participation in the museum's virtual programs would make possible a 'cultured' time in isolation, with emphasis on the values of education and intelligence.2 To put smaller museums in the spotlight and to help prevent their bankruptcy, the project 'Hermitage visiting colleagues' branched off from 'intelligent isolation' and used Hermitage's online platform to inform viewers about less well-known institutions.

For digital museology to remain competitive online, three challenges must be met. First, a proper assessment of the consumer sector and the changing multitude of existing art historical resources is required. Second, involvement and skillfulness among museum workers translates into an improved online presence. Over the last few years, Russia has started a process of 'rejuvenation' of an otherwise rigid industry. While the age category of the most active social media users in Russia ranges between 24 and 35 years old, the average age of museum workers is significantly more advanced. In 2014, only around 20 per cent of the staff at regional museums was under the age of $35.3 \mathrm{In}$ the longer term, museums will have to hire more younger workers with technological adeptness and an understanding of the interests of youthful social media users.

A third challenge is that none of the online activities and projects so far has become a direct source of income for institutions, even though museums have been among the cultural industries most affected financially during the self-isolation regime. The over one thousand private museums in Russia do not receive any financial aid, so that 60 per cent of them risk closure before the normalization of the situation. 4 The digital sphere may provide new revenue streams, including the possibility of commissioning digital content such as television documentaries. The experience of the quarantine has also provided incentives to monetize museums' existing online products, and museums may benefit from the fact that they offer more online educational courses than higher education institutions. $5 \mathrm{~A}$ specific direction which will probably be targeted in the future is the creation of additional educational resources for school-age children, given that they represent around 50 per cent of museum visitors, while only 17 per cent of current online content is suitable for the age group. 6 These facts illustrate how critical the need for digitalization is for the survival of museums which must maintain and even enlarge their audiences.

A survey on the impact of COVID-19 on museums in Europe conducted by the Network of European Museum Organizations shows that Russian museums display an overall greater diversification of digital services provided, for instance, through podcasts, live content, and quizzes. Nonetheless, according to the survey, social media are by far the most popular online services, which implies that public attention is almost exclusively drawn to its manifestations.

The recommendations and survey findings of NEMO further acknowledge that 'digital cultural heritage and digital engagement have demonstrated its value in the past weeks by bringing people together, encouraging creativity, sharing experiences, and offering a virtual space to build ideas collectively', which reflects the experience of Russian museums as well.7 Furthermore, the digitalization of museums worldwide offers innumerable opportunities for interinstitutional and international collaborative projects, unrestrained by geographic or bureaucratic limits. The programs we have initiated in Russia are an initial step.

\section{Conclusion}

This short article aimed to illustrate the state and the function of museum digital services in Russia during the COVID-19 pandemic, while integrating it within a broader European context. The new paradigm of insufficient budgeting and lengthy lockdown, as well as the prospect of having drastically decreased numbers of visitors due to social restrictions, demand the reconceptualization of the museum as a digital entity as much as a material one. It can even be said that the pandemic speeded up an already burgeoning process. By transitioning to a more effective digital presence, cultural organizations gain the possibility to re-establish themselves as places of social dialogue, comfort, and solace, strategies already being adopted in the Russian museum community. In doing so, museums have the opportunity to ensure their very survival. 


\section{Notes}

1 Zhanna Vasil'eva, 'Posle kovida v chetverg', Rossiiskaya Gazeta 78 (8132) 9 April 2020. https://rg.ru/2020/04/09/v-rossijskih-muzeiah-obsudili-sposoby-vyzhit-v-usloviiahpandemii.html, accessed 10 June 2020.

2 Hermitage Friends' Club, 'Intelligentnaya izolyatsiia. Kak posetit' Ermitaj 2 aprelya', 2 April 2020. https://support.hermitagemuseum.org/ru/news/view/150, accessed 30 May 2020.

3 Hermitage Friends' Club, 'Intelligentnaya izolyatsiia'.

4 Sergey Uvarov, 'Chastnoe slovo: pandemiu ne perezhyvut do $60 \%$ negosudarstfennyh muzeev. Yurediceskie slozhnosti i nekommercheskii status meshaiut im poluchit' gospodderzhku', Izvestiya, https://iz.ru/1016838/sergei-uvarov/chastnoe-slovo-pandemiiune-perezhivut-do-60-negosudarstvennykh-muzeev, accessed 28 May 2020.

5 Valery Gordin and Irina Sizova, 'Muzei v karantine i vokrug nego', National Research University Higher School of Economics, 27 May 2020. https://spb.hse.ru/news/368078640. $\underline{\mathrm{html}}$, accessed 15 June 2020.

6 Gordin and Sizova, 'Muzei v karantine i vokrug nego'.

7 Network of European Museum Organizations, 'Survey on the Impact of the COVID-19 Situation on Museums in Europe. Final Report', 2020, 3. https://www.ne-mo.org/advocacy/ our-advocacy-work/museums-during-covid-19.html, accessed 11 June 2020.

\section{Author}

Anna Guboglo

Institute for East European History

University of Vienna

Austria 